\title{
TWO MONOGRAPTUS SPECIES FROM THE PŘÍDOLÍ OF WESTERN TASMANIA
}

\author{
R.B. Rickards and M.R. Banks \\ (with one text-figure and one plate)
}

\begin{abstract}
Rickards, R.B. \& Banks, M.R., 1992 (31:x): Two Monograptus species from Př́idolí the of western Tasmania. Pap. Proc. R. Soc. Tasm. 126: 9-11. https://doi.org/10.26749/rstpp.126.9 ISSN 0080-4703. Department of Earth Sciences, University of Cambridge, Downing Street, Cambridge CB2 3EQ, United Kingdom (RBR); Department of Geology, University of Tasmania, GPO Box 252C, Hobart, Tasmania, Australia 7001 (MRB).

Monograptus parultimus Jaeger and M. cf. fragmentalis Bouček in siltstone with sparse shelly fossils in the Eldon Group near Bubs Hill, western Tasmania, indicate a basal Př́dolí age.
\end{abstract}

Key Words: Monograptus, Silurian, western Tasmania.

\section{INTRODUCTION}

Thomas (1960: pl. xiv) figured as Monograptus spp. specimenscollected by one of theauthors(MRB) prior to December 1956 from fawn to red siltstone in road cuts near the Q15 milepost on the Lyell Highway, about $1.75 \mathrm{~km} \mathrm{WNW} \mathrm{of}$ Bubs Hill, western Tasmania (Franklin 1:100 000 sheet 8013-971373, Department of Lands, Hobart). He identified them in the text (Thomas 1960: 15) as M. colonus et var., indicative of a Lower Ludlow age. These fossils came from a talus slope about $75 \mathrm{~m}$ on the Hobart side of the milepost, in a siltstone with ripple marks, brachiopods, bivalves, ostracodes, trilobites and crinoid fragments; from a cut about $33 \mathrm{~m}$ on the Hobart side of the milepost and from a small quarry $8 \mathrm{~m}$ on the Queenstown side of the milepost. The beds containing these fossils were ascribed to the Bell Shale (uppermost formation of the Eldon Group of Gill \& Banks, 1950) by Thomas (1960: 15), whereas Banks (1962: 181) correlated them with the Austral Creek Siltstone. This formation, which had been recently recognised by Blissett (1962) at Zeehan, lies under the Florence Quartzite, the formation beneath the Bell Shale. The Lyell Highway locality is shown as a correlate of the Amber Slate on the Department of Mines 1:50 000 geological map Lyell (Calver et al. 1987). The Amber Slate is separated from the Austral Creek Siltstone by the Keel Quartzite.

Reid (1964: 38, 39) reported monograptids in lightbrown, fissile, fossiliferous siltstone at $780 \mathrm{~m}$ (approx.) a.s.l. on a timber track northwest of Bubs Hill, at a locality with coordinates Franklin8013-98403875. The fossiliferous unit is overlain by a thin, fine-grained quartzite, a black unfossiliferous siltstone and then a correlate of the Florence Quartzite, the base of which is $32 \mathrm{~m}$ topographically above the graptolitic unit. With the graptolites in the siltstone are rugose corals, brachiopods, ophiuroids, asteroids, crinoids and hyolithids. Reid ascribed the fossiliferous siltstone to the Austral Creek Formation. Banks (in Talent \& Banks 1967: 158-159), following Reid, reported Maoristrophia sp., Notoleptaena sp., Dalmanites cf. wandongensis and Monograptus vulgaris curtus, the Dalmanites from the Lyell Highway locality. As with the unit on the Lyell Highway, this siltstone was shown on the Lyell geological sheet as an Amber Slate correlate. The Amber Slate is regarded as late Llandovery or Wenlock (Baillie 1989: 225, 232). Baillie (ibid: 232) commented that the Ludlow age ascribed earlier to the graptolites should be treated with caution.
The graptolites collected by Reid were sent away soon after collection for expert identification but were mislaid until they were recovered through the good offices of Dr Barry Webby in mid-1989, after which they were drawn to the attention of the senior author (RBR). A few identifiable fragments have since been found in the road cut.

\section{PALAEONTOLOGY}

Monograptus cf. fragmentalis Bouček, 1936

(fig. $1 \mathrm{~A}$ and pl. $1 \mathrm{~A}$ )

1936 Monograptus fragmentalis n. sp.; Bouček, 7, text figs. 11-n.

1943 Pristiograptus fragmentalis (Bouček, 1936); Pribyl 2728; text fig. II, R.S.

1967 Monograptus vulgaris curtus Elles \& Wood; Banks in Talent \& Banks: 158.

1976 Pristiograptus fragmentalis (Bouček); Bouček, Mihajlovic and Veselinovic, 88-91; pl. 2, figs 1-7; pl. 3 , fig. 1; text figs $2 \mathrm{a}-\mathrm{me}$.

1986 Monograptus fragmentalis Bouček, 1936; Jaeger, 1986, 316; pl. 2, figs 14-15, 18, 20-21.

Material

About twenty specimens, including fragments possibly referable to this form, ocur on slabs, Department of Geology, University of Tasmania catalogue numbers 80821 , 80838 and 80856 . Possible fragments also occur on 80869 and 80872 . All specimens are from one locality, a timber track near Bubs Hill, western Tasmania (coordinates of locality: Franklin 8013-98403875, approximately $\left.42^{\circ} 06^{\prime} \mathrm{S}, 145^{\circ} 46^{\prime} \mathrm{E}\right)$.

\section{Associates}

Occurs with $M$. cf. parultimus.

\section{Horizon}

Eldon Group.

\section{Remarks}

The material seems to be quite close to that recently described by Jaeger (1986) from the type Prídolí region. There are proximal and distal fragments, which do not occur on the same specimen, but which have similar thecal type and are 


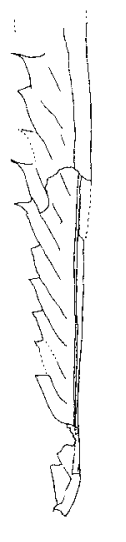

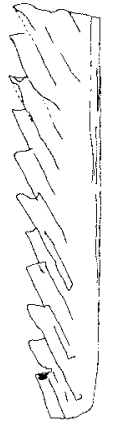

(ii)

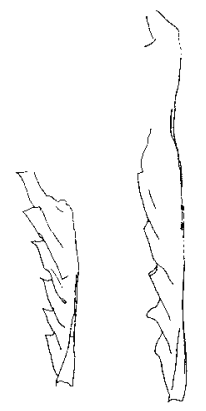

(iii)

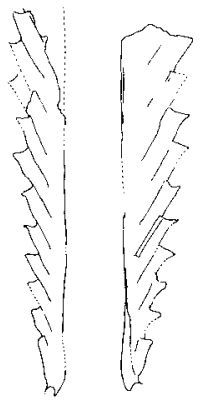

(iii)

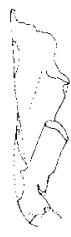

(iv)
FIG. 1 - (A) M. cf. fragmentalis Bouček: (i) UTGD 80856, $\times$ 4; (ii) UTGD 80855, × 4; (iii) UTGD 80881, × 4; all from timber track. (B) M. parultimus Jaeger: (i) UTGD 80872, × 4; (ii) UTGD 80850, × 4; (iii) UTGD 80848, $\times$ 4; (iv) UTGD 124100, $\times$ 4; (i), (ii) and (iii) from the timber track, (iv) from cutting on the Lyell Highway.

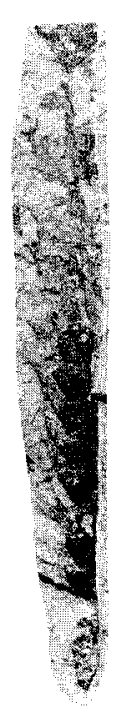

(i)

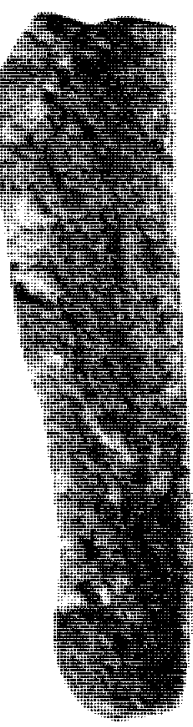

(ii)

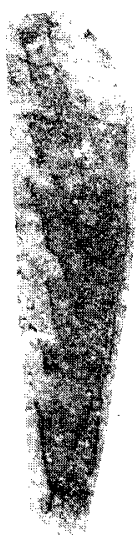

(iii)

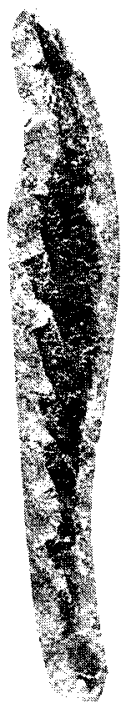

(i)

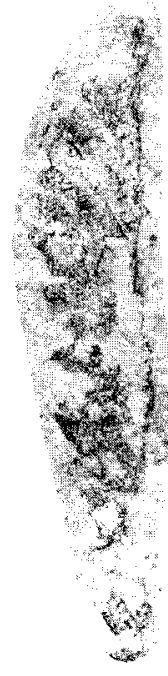

(ii)
日 probably the same form. The proximal thecal overlap begins at about the level of the aperture of the preceding theca; in the distal, fragments reach just below the aperture of the preceding theca. (Thus, a secrion just above the thecal apertures will traverse three thecal tubes before the dorsal margin/nema is reached.) This is a slightly greater thecal overlap than indicated by Jaeger, but the thecal spacing, at 12 in $10 \mathrm{~mm}$, is well within the range quoted. The proximal end is rather dubiuslike and varies from almost straight to (usually) gently ventrally curved. The sicula itself is almost $2 \mathrm{~mm}$ long and its apex is just below the aperture of the second theca. In subdorsal view (fig. 1), some specimens show what appear to be apertural denticles, but this is certainly a feature of the particular view and a degree of diagenetic flattening: in the true profile, none of the thecae show denticles, though there is a suggestion of very gently undulating apertural rims. The dorsoventral width exceeds $2.5 \mathrm{~mm}$ even in fragments preserved in three dimensions. As far as we are aware, these are the first recordings from Australia of forms related to this species. In Europe (Jaeger 1986), M. fragmentalis usually occurs in the latest Ludlow, immediately below the parultimus Zone at the base of the Pridolí, but the species is known to overlap with $M$. parultimus in one location (Serbia).

\section{Monograptus parultimus Jaeger, 1975 (fig.1B and pl. 1B)}

1899 Monograptus ultimus n. sp; Perner, 13-14, pl. 16, figs 4, 5?, $11 \mathrm{a}, \mathrm{b}$ (non text-figs $14 \mathrm{a}, \mathrm{b}=$ M. ultimus)

1940 Monograptus (Pristiograptus) ultimus Perner; Pribyl, pl. 1, figs 9, 10, ?11.

?1974 Pristiograptus (?) ultimus (Perner); Paskevicius, fig. 1, plate 14 , figs 3-8.

1975 Monograptus parultimus n. sp.; Jaeger, 119-125; textfig. 4, p. 2, fig. 4, 8 .

1976 Pseudomonoclimacis ultimus (Perner); Tsegelnjuk, 106, p. 30, figs 10-12.

1976 Pseudomonoclimacis podolicus sp. nov.; Tsegelnjuk, 106-107, p. 31, figs 1-3.

1979 Monoclimacis parultimus (Jaeger); Paskevicius, 160-2, pl. 10, figs 1-5; pl. 24, figs 16-19; pl. 25, figs $1-5$.

1983 Ludensograptus parultimus (Jaeger); Tsegelnjuk, 94, 145.

1986 Monograptus parultimus Jaeger, 1975; Jaeger, 318321, text-figs 29-34; pl. 1, figs 1-2, 8-9; pl. 2, figs 36, 23-24; pl. 4, fig. 12.

\section{Material}

There are five fairly well-preserved specimens, in three dimensions with fine mud infills, and a further fifteen or so fragments may be referable to this form, on Department of Geology, University of Tasmania, slabs $80848,80850,80854$, 80855,80872 . All these specimens are from the locality given for $M$. cf. fragmentalis above. There are also two fragments from the road cutting on the Lyell Highway, 50022 and 124100.

\section{Associates}

It occurs with $M$. cf. fragmentalis Bouček.

Horizon

Eldon Group. visible, especially of th 1, th $\times 12$; indifferently preserved specimen, but showing undulating thecal apertures quite well, at least up to th6. 


\section{Remarks}

M. parultimus is distinguished from $M$. cf. fragmentalis at the same locality by the presence of rounded thecal apertures or undulating thecal margins. The sicula, although of similar dimensions and position, is almost always strongly curved in a ventral sense, with a strong dorsal tongue. Only a few specimens are almost straight, though the rhabdosome itself is proximally straighter than in $M$.cf. fragmentalis. The thecal dimensions, spacing, and overall appearance of the colony, preserved in moderate three dimensions, are close to the figures given by Jaeger (1986). The only difference we can detect is that the gentle sigmoidal curvature of the thecae is even less conspicuous than in Jaeger's material. Nevertheless, it is present. The early growth of the first theca is typically upwards at a low angle, but perhaps the sicular apertural region is less isolated (i.e. the th 1 bud is lower down) than in Prídolí material. The preservation, in fact, may obscưre both these differences, which may be more apparent than real. $M$. parultimus has not previously been recorded from Australia, and its association in some numbers with $M$. cf. fragmentalis does suggest an horizon at the base of the Pridoli, near the base of the parultimus Zone.

\section{SIGNIFICANCE}

The fossils are significant in two respects - biogeographical and stratigraphical.

The recognition of these two species extends their geographical range to Australia. $M$. fragmentalis was recorded by Jaeger (1986) from Bohemia and Yugoslavia (eastern Serbia, Ruj Mountains and Potok Zajednmica), the last being the Dubsky Potok of Bouček(1936). M. parultimus has been recorded by Jaeger (1986) from the eastern European platform in the Soviet Union, the Carnic Alps in Austria, and the Raj Mountains (eastern Serbia). It is at Potok Zajednica that the two species occur together, enabling us to suggest a horizon near the base of the Prídolí. Jaeger (1986) notes that $M$. ultimus occurs in four continents, but M. parultimus, as yet, is less widely recorded, perhaps because of its relatively more recent definition and the fact that in badly preserved material its definitive features might be missed: it would probably be then identified as Pristiograptus dubius (Suess), or as M. ultimus (e.g. Paskevicius 1974; see synonymy).

Stratigraphically, the age determination based on these two monograptid species removes the only evidence of Ludlow age for fossils in western Tasmania and provides support for Baillie's suggestion for a depositional hiatus in western Tasmania in the Ludlow (Baillie 1989: 232). However, it does raise the possibility (contra Baillie 1989: 233 ) that there is only a single major fining upward cycle in western Tasmania in the Llandovery and Wenlock, and two such major cycles in the Prídolí to Pragian or Emsian. A stratigraphic discontinuity at the base of the Keel Quartzite becomes a possibility.

\section{ACKNOWLEDGEMENTS}

We are grateful to Doris Banks and Penny Partridge for assistance in collecting. in the field.

\section{REFERENCES}

Banı..1E, P.W., 1989: Silurian and Devonian sediments. In Burrett, C. F. \& Martin, E.L. (Eds): GEOLOGY AND MINERAL RESOUVCES OF TASMANIA. Geol. Soc. Aust., Spec. Publ. 15: 224-233.

BANKS, M.R., 1962: The Silurian and Devonian Systems. In Spry, A.H. \& Banks, M.R. (Eds): THE GEOLOGY AND MINERAL RESOURCES OF TASMANIA. J. Geol. Soc. Aust. 9(2): 177--188.

Busser"1, H.A., 1962: Zeehan, Tasmania. Tasm. Dep. Mines 1 mile Geol. Atlas Ser., Explan. Rep., Sheet 50 (7914S).

Bouč:k, B., 1936: La faune graptolithique du Ludlowien inférieur de la Boheme. Bull. intern. Acad. Sci. Boheme 1936: 1-16.

Botček, B., Mihajlovic, M. and Vesfilinovic, M., 1976: Graptolites of Upper Silurian and Lower Devonian of Zvonacka Banja (Eastern Serbia). Glas coxcui Acad. Serbe Sci. Arts. C7. Sci. Math. Nat. 39: 79-114.

Cal.yer, C.R. F:T Al., 1987: Lyell, Tasmania. Tasm. Dep. Mines 1: 50,000 Geol. Atlas Ser., Sheet 8013N.

Gll., E.D. \& BANks, M.R., 1950: Silurian and Devonian stratigraphy of the Zeehan area. Pap. Proc. R. Soc. Tasm. (1949): 259271.

JAEG:R, H., 1975: Die Graptolithenfuhrung in Silur/Devon des Cellon-Profils (Karnische Alpen). Carinthic II, 165/185: 111-126.

JAEger, H., 1986: In Kriz, J. et al: Prídolí - the Fourth Subdivision of the Silurian. Jb. Geol. B.-A. 129: 291-360.

Paskevicius, I.Y., 1974: Graptoliti i zonalnoe paschlenenie Ludlovskich otloschenii v pribaltike. Izdatelstuo 'Nauka'. Sibirskoe otdeleiie Novosibirsk 1974. Graptoliti SSSR Trudi I Osesoyoznogo Kollokviyma: 122-134, 164-188.

PASKEVICIUS, J., 1979: BIOSTRATIGRAPHY AND GRAPTOLITES OF THE LITHUANIAN SILURIAN. Vilnius: 1-267.

Parner, J., 1899: ETUDES SUR LES GRAPTOLITES DE BOHEME. III. Monographie des Graptolites de L'Ftage E. Section 6. Prague: 1-24.

Přkil, A., 1940: Die Graptolithenfauna des mittleren Ludlow von Bohmen (oberes e B), Vest. Stat. Geol. Ust. C.S.R. 16: 6373.

P̌̌liıY, A., 1943: Revision allor Vertreter der Galtung Pristiograptus aus der Gruppe P. dubius und P. vulgaris aus dem bohmischen und auslandischen Silur. Mitt. tschech. Akad. Wiss. 52/4: 149.

Reil), K.O., 1964: Geology of the Princess River area. Unpubl. B.Sc. Hons. Thesis, University of Tasmania.

TALENT, J.A. \& BANKS, M.R., 1967: Devonian of Victoria and Tasmania. In Oswald, D. H. (Ed.): INTERNATIONAL SYMPOSIUM ON THE DEVONLAN SYSTEM. Alberta Soc. Petrol. Geol. Calgary, Alberta II: 147-163.

THOMAs, D.E., 1960: The zonal distribution of Australian graptolites. Proc. R. Soc. NSW 94: 1-58.

TsfofinjuK, P.D., 1976: Late Silurian and Early Devonian Monograptidae of the south-west Ukrainian East-European Platform. Palaeontology and Stratigraphy of the upper Precambrian and lower Palaeozoic of the south-western EastEuropean Platform, Kiev: 91-133.

Tseghinjuk, P.D., 1983: The Silurian of Podolia, the guide of the excursion. Naukova Dumka, Kiev: 1-222.

(accepred 3 May 1991) 